\title{
Arctic Plants Produce Vastly Different Numbers of Flowers in Three Contrasting Years at Lake Hazen, Quttinirpaaq National Park, Ellesmere Island, Nunavut, Canada
}

\author{
Zoe A. PANCHEN
}

Department of Biology, Carleton University, 1125 Colonel By Drive, Ottawa ON K1S 5B6 Canada; email: Zoe.Panchen@ Carleton.ca

Panchen, Zoe A. 2016. Arctic plants produce vastly different numbers of flowers in three contrasting years at Lake Hazen, Quttinirpaaq National Park, Ellesmere Island, Nunavut, Canada. Canadian Field-Naturalist 130(1): 56-63.

To maximise reproductive success in the short Arctic growing season, plants pre-form flower buds the year prior to flowering. Flower bud production depends on warm ambient temperatures. Thus, although currently Arctic plants have low rates of sexual reproductive success, the warming climate may increase reproductive success. Following the long, warm growing season in 2012, plants at Lake Hazen, Ellesmere Island, produced many flowers in the short, cold growing season of 2013. Conversely, few flowers were produced in 2014, a long, warm growing season, but many flowers were produced in 2015, another long, warm growing season. Potentially higher rates of reproductive success in a warming climate could be compromised if consecutive years do not have long, warm growing seasons.

Key Words: Arnica angustifolia; Narrow-leaved Arnica; Cassiope tetragona; Arctic White Heather; Pedicularis capitata; Capitate Lousewort; climate change; flowering; flower abundance; reproductive success

\section{Introduction}

To maximise sexual reproductive success in the short Arctic growing season and to minimise time spent developing flower buds at the beginning of the growing season, many Arctic plants pre-form their flower buds in the year or years prior to flowering (Sørensen 1941). Of the complete flora of 184 species and varieties found in northeastern Greenland, for example, $80 \%$ pre-form their flower buds (Sørensen 1941). Given the circumpolar nature of Arctic flora, a similar proportion of the 125 species known to grow in the vicinity of Lake Hazen, Quttinirpaaq National Park, Ellesmere Island, Nunavut, Canada, likely also pre-form their flower buds (Sørensen 1941; Porsild and Cody 1980; Soper and Powell 1985; Elven 2003).

The extent to which the pre-formed flower bud primordia differentiate before the onset of winter varies among species but by August, differentiation has reached the extent to which it will differentiate in that year (Sørensen 1941). By winter, the flower buds of Cassiope tetragona (L.) D. Don (Arctic White Heather; Itsutit [Aiken et al. 2007]; Ericaceae) are fully formed with developed pollen visible, whereas those of Arnica angustifolia Vahl (Narrow-leaved Arnica; Qursuqtainnarmik nunaralik [Mallory and Aiken 2012]; Asteraceae) and some Pedicularis spp. L. (Orobanchaceae) are only partially formed, with anthers and petals visible and the ovary partially formed but no ovules visible (Sørensen 1941).

Flower abundance of some Arctic and alpine species is influenced by temperatures in the summer or autumn of the preceding year or by snow depth in the winter just prior to flowering. Flower abundance of Dryas integrifolia Vahl (Mountain Avens; Malikkaat [Aiken et al. 2007]; Rosaceae) and Saxifraga oppositifolia L. (Purple
Saxifrage; Aupilattunnguat [Aiken et al. 2007]; Saxifragaceae) at Tanquary Fiord, Quttinirpaaq National Park, Ellesmere Island, Nunavut, is influenced by August and October mean minimum temperature, respectively, in the year preceding flowering (Panchen and Gorelick 2015). In Zackenbergdale, Greenland, the flower abundance of C. tetragona, Salix arctica Pall. (Arctic Willow; Supitit [Aiken et al. 2007]; Salicaceae) and Papaver radicatum Rottb. (Arctic Poppy; Igutsat niqingit [Mallory and Aiken 2012]; Papaveraceae) are influenced by the sum of temperatures above $0^{\circ} \mathrm{C}$ (heat sum) in the preceding year's growing season, while flower abundance of Dryas species is influenced by snow depth in the preceding winter and heat sum in the preceding and current growing seasons (Høye et al. 2007; Ellebjerg et al. 2008). In Svalbard, Norway, C. tetragona flower abundance is influenced by snow depth in the context of extreme weather events, where shallow snow depth and an extremely warm spell mid-winter resulted in reduced flower numbers the following summer (Semenchuk et al. 2013). In the alpine setting of the Rocky Mountains in Colorado, flower abundance of Delphinium nelsonii Greene (Twolobe Larkspur; Ranunculaceae) was influenced by snow depth in the preceding winter, where it is thought that shallower snow depths in more recent years may have exposed the flower buds to frost damage (Inouye and McGuire 1991). In the same area, flower abundance of Androsace septentrionalis L. (Pygmyflower Rock Jasmine; Primulaceae), an annual or short-lived perennial, was influenced by the preceding year's summer precipitation and May temperature in the year of flowering but not the preceding year's growing season temperatures (Inouye et al. 2003).

A contribution towards the cost of this publication has been provided by the Thomas Manning Memorial Fund of the Ottawa Field-Naturalist's Club. 
The Canadian Arctic Archipelago experienced dramatically different weather during each of the growing seasons from 2012 to 2015, leading to growing season lengths and temperatures that differed substantially over the four years. At Lake Hazen, Quttinirpaaq National Park, Ellesmere Island, Nunavut $\left(81.82^{\circ} \mathrm{N}, 71.35^{\circ} \mathrm{W}\right)$, 2012 and 2015 were warm years with long growing seasons, while 2013 was a cold, snowy year with a short growing season and 2014 was a dry year with very little snow and a growing season length and temperatures intermediate between 2013 and 2015. Vastly more flowers were observed on plant species at Lake Hazen in 2013 and 2015 compared with 2014. This article presents critical baseline natural history data on Canadian high Arctic flowering phenology in a part of Canada that is rarely surveyed. Moreover, it documents the effects of variable weather conditions on Arctic plant flower production.

\section{Methods}

The flowering progression of three species, $A$. angustifolia, C. tetragona and Pedicularis capitata Adams (Capitate Lousewort; Kukiujait [Aiken et al. 2007]; Orobanchaceae), was monitored at Lake Hazen, Quttinirpaaq National Park, from $13^{\text {th }}$ June to $31^{\text {st }}$ July in 2013, 2014 and 2015 (Figure 1). A population of

A
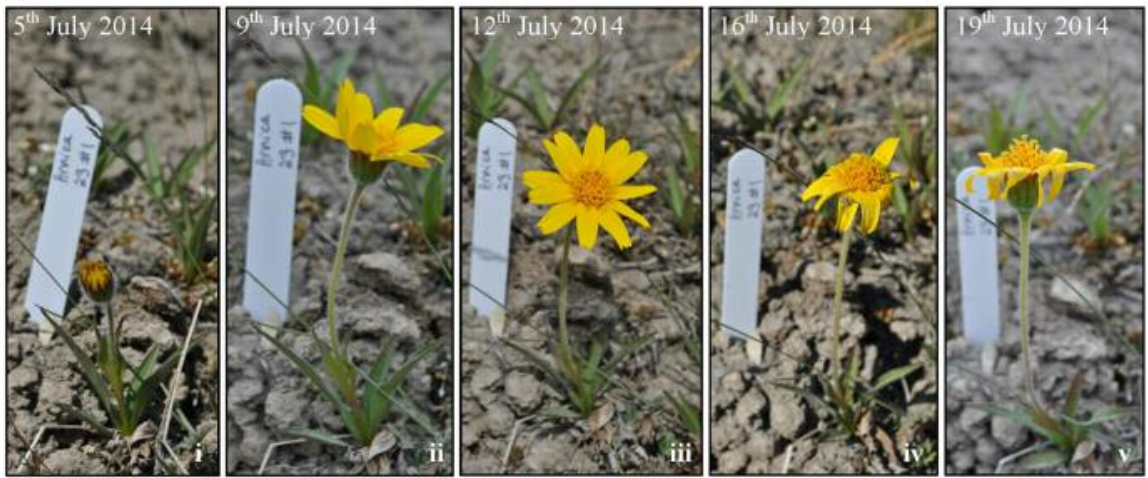

B
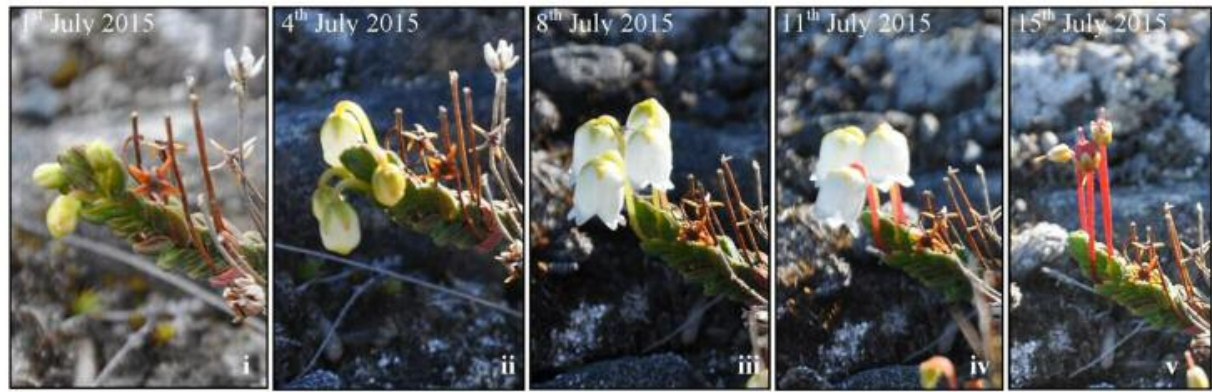

C
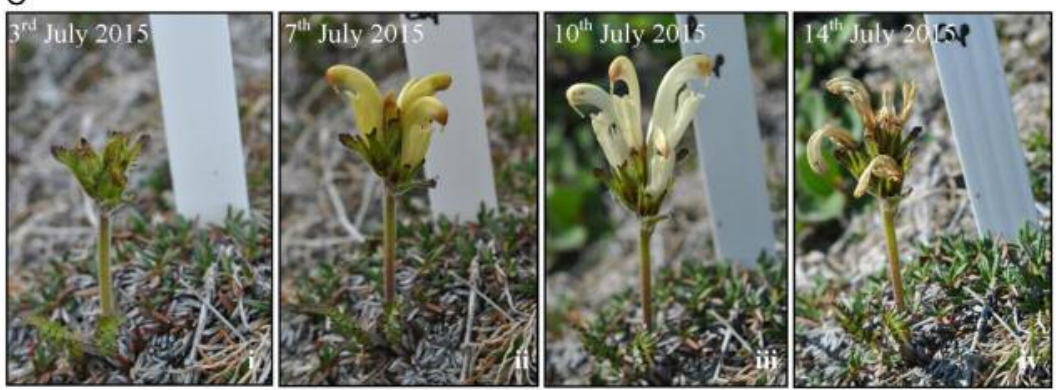

FIGURE 1. Flower progression of (A) Arnica angustifolia (Narrow-leaved Arnica) (B) Cassiope tetragona (Arctic White Heather) and (C) Pedicularis capitata (Capitate Lousewort) at Lake Hazen, Quttinirpaaq National Park, Ellesmere Island, Nunavut, Canada, showing flower(s) in bud (Ai, Bi and ii, and Ci), open flowers (Aii and iii, Biii and iv, and Cii and iii) and finish of flowering (Aiv and v, Bv and Civ). Photos: Zoe A. Panchen (panels A and C), Carly Cassey (B). 
the perennial $A$. angustifolia was monitored on a southwest facing stream bank southeast of McGill Mountain $\left(81.85^{\circ} \mathrm{N}, 71.35^{\circ} \mathrm{W}\right)$, a population of the woody species $C$. tetragona was monitored in a northeast facing gully on McGill Mountain $\left(81.95^{\circ} \mathrm{N}, 71.49^{\circ} \mathrm{W}\right)$ and a population of the perennial $P$. capitata was monitored on the shores of Skeleton Lake $\left(81.83^{\circ} \mathrm{N}, 71.48^{\circ} \mathrm{W}\right)$. Areas with established populations of each species were selected as monitoring sites before flowering began in 2013, except in the case of $A$. angustifolia, which only grows in a few locations at Lake Hazen and was not found until it was already in flower in 2013.

The sites were visited every $3-4$ days in all 3 years. In 2013, monitoring was qualitative and subjective, following an approach successfully used by Panchen et al. (2012), wherein the date of first flower, peak flowering and finish of flowering of each population was recorded. After reviewing the 2013 results, the approach for subsequent years was changed to counting flowers to provide a more definitive date for start, peak and finish of flowering. Thus, in 2014 and 2015, monitoring was quantitative wherein 30 plants in each population were randomly tagged before flowering started and the number of flowers on each tagged plant was counted every 3-4 days. The inflorescence (capitulum holding many small flowers) of $A$. angustifolia was counted as a single flower.

The start, peak and finish of flowering for each species were determined from the flower count of the tagged plants. Start of flowering was defined as the date on which open flowers (Figure 1) were first observed on the 30 tagged plants, peak flowering as the date on which the greatest number of open flowers was counted and finish of flowering as the first date at the end of flowering on which no open flowers were observed. For each species, the peak number of flowers produced on the 30 tagged plants and the number of tagged plants that flowered in 2013-2015 were compared. For 2013, the peak number of flowers produced on 30 plants and the number of plants flowering out of 30 plants were estimated from observational field notes and pho- tographs of the population or individual plants when they were in peak flower.

May to September mean monthly temperatures for the individual years 2012-2015 and the 10-year (20012010) and 30-year (1981-2010) means at Eureka Weather Station, Ellesmere Island, Nunavut, Canada, were obtained or calculated from Environment Canada (2015) data. The Eureka Weather Station $\left(79.59^{\circ} \mathrm{N}\right.$, $85.56^{\circ} \mathrm{W}$ ) is the closest weather station to Lake Hazen and experiences a similar climate, with temperatures between the two locations well correlated (Soper and Powell 1985; Edlund and Alt 1989; Thompson 1994).

\section{Results}

Flower abundance of $A$. angustifolia, C. tetragona and $P$. capitata populations was much greater in 2013 and 2015 than in 2014 (Table 1, Figures 2 and 3). Compared with 2014, in 2013 and 2015 there were 1.5 times more flowers on tagged $A$. angustifolia plants and 1.5 times more $A$. angustifolia tagged plants flowering; 273 times more $C$. tetragona flowers and 2.5 times more $C$. tetragona plants flowering; and 6.3 times more $P$. capitata flowers and 2.3 times more $P$. capitata plants flowering (Table 1).

Of the 4 years 2012-2015, 2012 was the warmest growing season with the May-September mean temperature at Eureka $1.81^{\circ} \mathrm{C}$ and $2.32^{\circ} \mathrm{C}$ warmer than the 10 - and 30-year means, respectively (Table 2 ). The coldest growing season occurred in 2013, with the May-September mean temperature $3.05^{\circ} \mathrm{C}$ and $2.54^{\circ} \mathrm{C}$ colder than the 10- and 30-year means, respectively. Mean monthly temperatures were above $0^{\circ} \mathrm{C}$ for a month longer in 2012, 2014 and 2015 than in 2013 suggesting that 2013 had a shorter growing season than the other 3 years.

Arnica angustifolia and P. capitata started, peaked and finished flowering earlier in 2014 and 2015 than in 2013 (Table 3), corroborating temperature data, which indicated that the growing season was likely longer in 2014 and 2015 than in 2013. Cassiope tetragona started flowering earlier in 2014 and 2015 than in 2013 and peaked and finished flowering earlier in 2015 than in

TABLE 1. Comparison of number of flowers per population on the date of peak flowering (Table 3) and number of tagged plants that produced flowers (30 tagged plants in each population) of Arnica angustifolia (Narrow-leaved Arnica), Cassiope tetragona (Arctic White Heather), and Pedicularis capitata (Capitate Lousewort) over 3 years at Lake Hazen, Quttinirpaaq National Park, Ellesmere Island, Nunavut, Canada.

\begin{tabular}{lrrrrrr}
\hline \hline & \multicolumn{3}{c}{$\begin{array}{c}\text { No. flowers on date } \\
\text { of peak flowering }\end{array}$} & & \multicolumn{2}{c}{$\begin{array}{c}\text { No. tagged plants that } \\
\text { flowered }\end{array}$} \\
\cline { 2 - 7 } Species & $2013^{*}$ & 2014 & 2015 & $2013^{*}$ & 2014 & 2015 \\
\hline Arnica angustifolia & 30 & 20 & 31 & 30 & 20 & 30 \\
Cassiope tetragona & 9000 & 33 & 9316 & 30 & 12 & 30 \\
Pedicularis capitata & 75 & 12 & 76 & 30 & 13 & 30 \\
\hline \hline
\end{tabular}

*2013 numbers are estimates. 

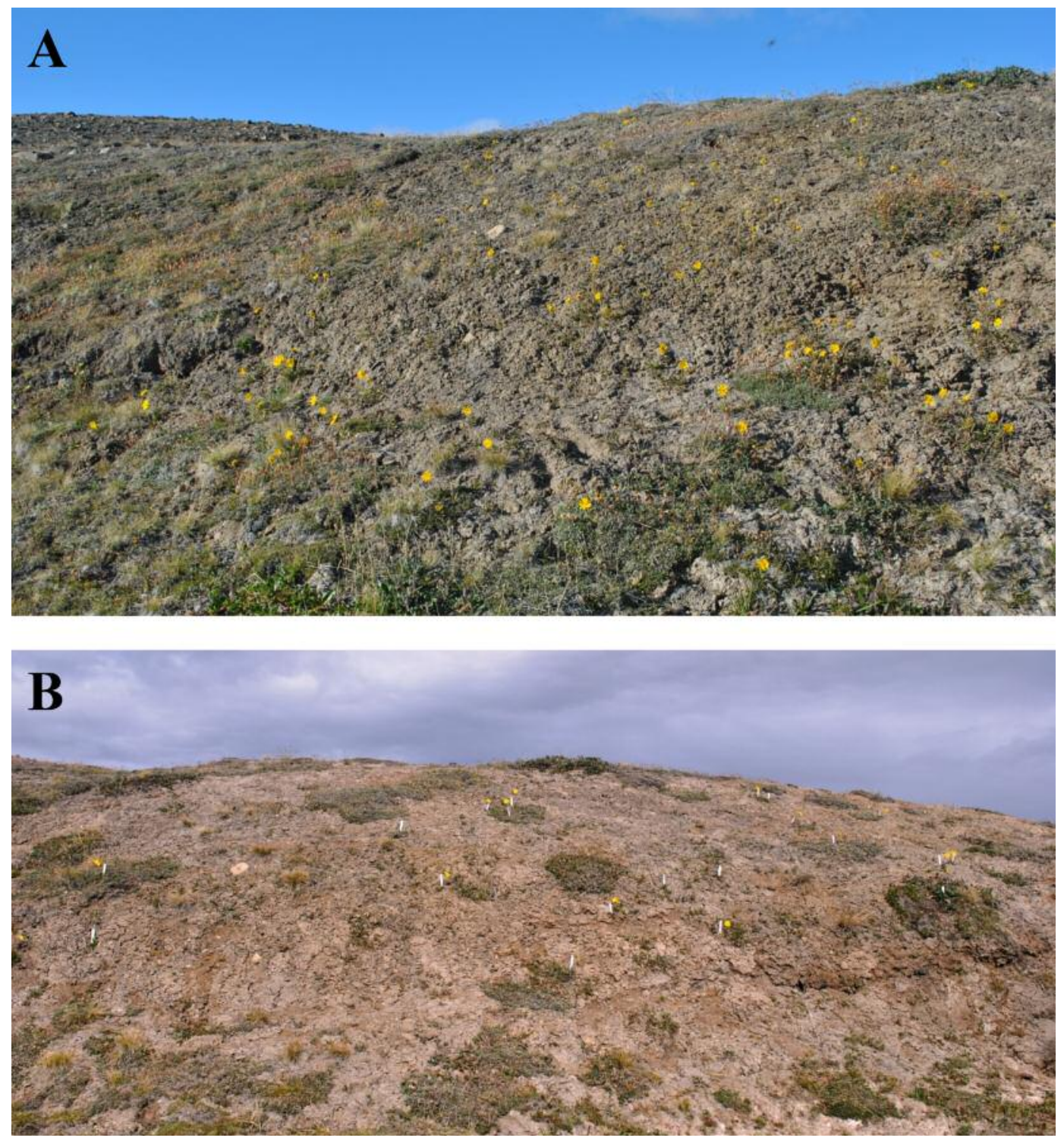

FIGURE 2. Arnica angustifolia (Narrow-leaved Arnica) population on a southwest facing stream bank, southeast of McGill Mountain, Lake Hazen, Quttinirpaaq National Park, Ellesmere Island, Nunavut, Canada. Over 100 flowers are visible in the 2013 photograph (A) and just 20 flowers (marked with white plastic plant tags) in 2014 (B). Both photos are of the same site taken from approximately the same position and angle but B is at a lower magnification than A. The patch of vegetation at the top right of $\mathrm{A}$ is on the centre skyline in $\mathrm{B}$ and the dip in the centre skyline in $\mathrm{A}$ is on the left in B. Photos: Zoe A. Panchen.

2013 and 2014. The A. angustifolia population was found on the last day at Lake Hazen in 2013 and was deemed to be at or close to peak flowering on that day because no flower buds remained and the majority of the plants had fresh-looking flowers, i.e., few of the ray flowers around the edge of the capitulum were wilting. Given the time from start to peak flowering at Lake Hazen in 2014 and 2015 of 7 and 4 days, respectively (Table 3), A. angustifolia likely started flowering later in 2013 than in 2014 and 2015. 

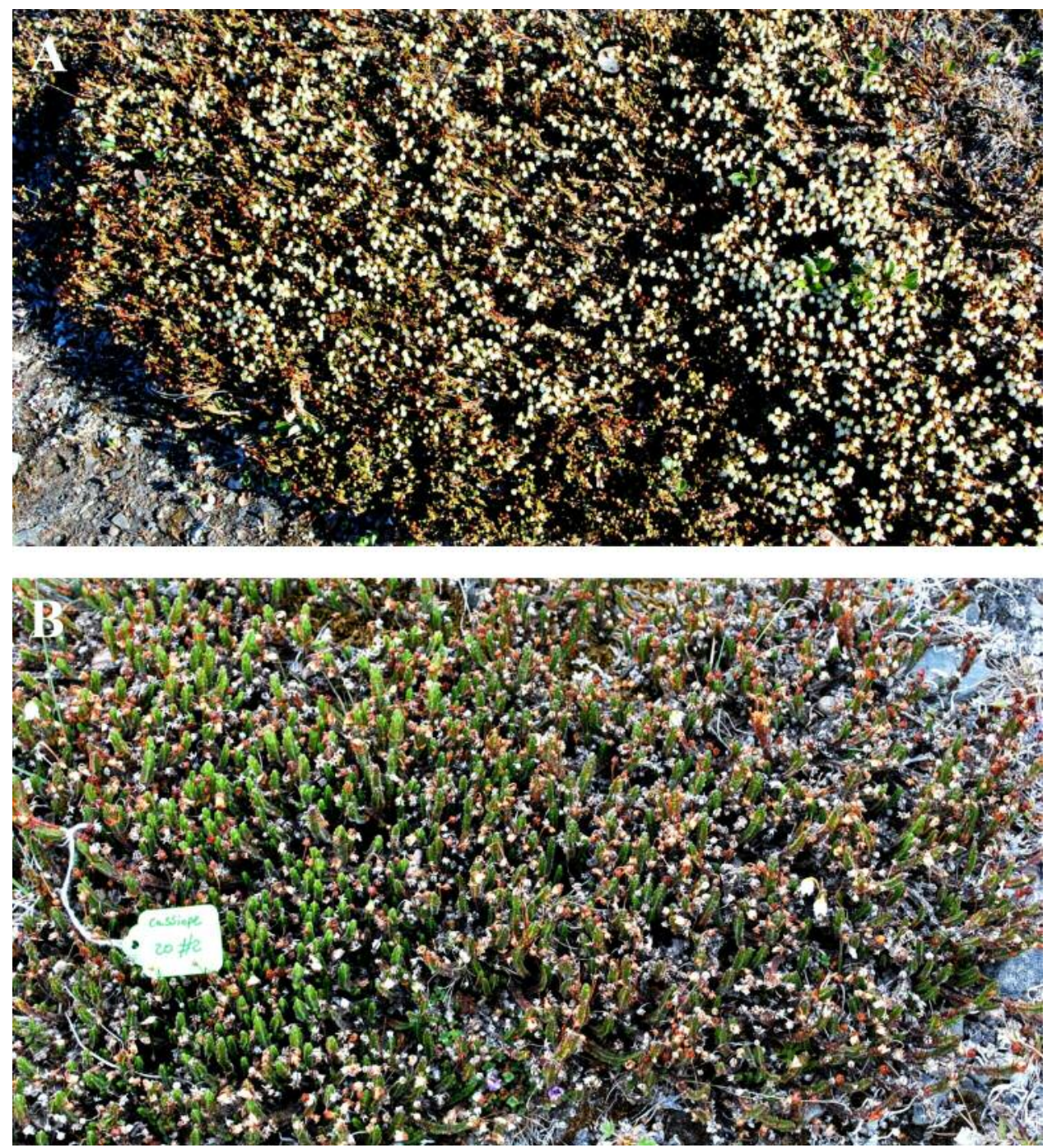

FIGURE 3. Cassiope tetragona (Arctic White Heather) in a northeast facing gully on McGill Mountain, Lake Hazen, Quttinirpaaq National Park, Ellesmere Island, Nunavut, Canada with over 300 flowers in 2013 (A) and with just three flowers in 2014 but over 100 flowers/fruits from 2013 still visible (B).

TABLE 2. Mean monthly temperature $\left({ }^{\circ} \mathrm{C}\right)$ from May to September, 2012-2015, compared with 10-year (2001-2010) and 30year (1981-2010) means at Eureka Weather Station, Ellesmere Island, Nunavut, Canada. Source: Environment Canada (2015).

\begin{tabular}{|c|c|c|c|c|c|c|}
\hline Month & 2012 & 2013 & 2014 & 2015 & $\begin{array}{c}10 \text {-year } \\
\text { mean }\end{array}$ & $\begin{array}{c}30 \text {-year } \\
\text { mean }\end{array}$ \\
\hline May & -9.40 & -12.31 & -8.50 & -12.60 & -9.45 & -10.20 \\
\hline June & 5.40 & 0.50 & 1.00 & 4.30 & 3.49 & 3.00 \\
\hline July & 8.60 & 4.45 & 5.85 & 9.60 & 5.50 & 6.10 \\
\hline August & 5.10 & -1.14 & 4.27 & 4.10 & 4.19 & 3.20 \\
\hline September & -2.40 & -8.50 & -4.62 & -5.10 & -5.47 & -6.40 \\
\hline Average, May-Sept. & 1.46 & -3.40 & -0.40 & 0.06 & -0.35 & -0.86 \\
\hline Average, June-Aug. & 6.37 & 1.27 & 3.71 & 6.00 & 4.39 & 4.10 \\
\hline
\end{tabular}


TABLE 3. Dates for start, peak, and finish of flowering of Arnica angustifolia (Narrow-leaved Arnica), Cassiope tetragona (Arctic White Heather) and Pedicularis capitata (Capitate Lousewort) over 3 years at Lake Hazen, Quttinirpaaq National Park, Ellesmere Island, Nunavut, Canada.

\begin{tabular}{|c|c|c|c|c|}
\hline Species & Year & $\begin{array}{c}\text { Start of } \\
\text { flowering }\end{array}$ & $\begin{array}{l}\text { Peak flowering } \\
\text { (days since start } \\
\text { of flowering) }\end{array}$ & $\begin{array}{l}\text { Finish of flowering } \\
\text { (days since start } \\
\text { of flowering) }\end{array}$ \\
\hline \multirow[t]{3}{*}{ Arnica angustifolia } & 2013 & —* & 31 July & $>31$ July $\dagger$ \\
\hline & 2014 & 5 July & 12 July (7) & 22 July (17) \\
\hline & 2015 & 9 July & 13 July (4) & 23 July (14) \\
\hline \multirow[t]{3}{*}{ Cassiope tetragona } & 2013 & 12 July & 19 July (7) & $>31$ July \\
\hline & 2014 & 2 July & 22 July (10) & $>31$ July† \\
\hline & 2015 & 27 June & 8 July (11) & 23 July (26) \\
\hline \multirow[t]{3}{*}{ Pedicularis capitata } & 2013 & 18 July & 21 July (3) & $>31$ July† \\
\hline & 2014 & 7 July & 10 July (3) & 13 July (6) \\
\hline & 2015 & 7 July & 10 July (3) & 20 July (13) \\
\hline
\end{tabular}

*Not found until after start of flowering.

$\dagger$ Not finished flowering when the Lake Hazen site was vacated on $31^{\text {st }} \mathrm{July}$.

\section{Discussion}

The number of flowers in populations of three Arctic plant species at Lake Hazen was dramatically different in 2014 than in 2013 and 2015. There were many flowers in a year with a cold, short growing season (2013) following a year with a warm, long growing season (2012). There were few flowers in a year with a warm, long growing season (2014) following a year with a cold, short growing season (2013). There were many flowers in a year with a warm, long growing season (2015) following a year with a warm, long growing season (2014). Possible reasons for the low flower abundance in 2014 could be that the 2013 growing season might have been too short or temperatures may not have been warm enough for the species to pre-form flower buds (Sørensen 1941; Høye et al. 2007; Ellebjerg et al. 2008; Panchen and Gorelick 2015). In 2013, the mean temperature in August, the month in which flower bud differentiation is suspended (Sørensen 1941), was already below freezing but was above freezing in 2012, 2014 and 2015. Another possible reason is that the three species may have exhausted their available nutrient and carbohydrate resources in the sexual reproductive cycle in 2013 and, hence, did not have enough resources available to pre-form buds in 2013 for the 2014 flowering season. Arctic plants are generally resource limited and may not flower every year as they must build up enough nutrients and carbohydrates over 1 or more years for the resource-intensive sexual reproductive cycle (Mooney and Billings 1960; Fox and Stevens 1991; Wookey et al. 1993; Pielou 1994).

Of the three species studied, C. tetragona is the only one considered a snow bed species, it relies on the insulation of snow cover to protect the aboveground preformed flower buds from the harsh Arctic winters (Soper and Powell 1985). At Lake Hazen, it grows in gullies, depressions and on the lee side of hills where snow drifts form. In 2013, the gully on McGill Mountain was filled with approximately $30 \mathrm{~cm}$ of snow on $20^{\text {th }}$ June and was not free of snow until $2^{\text {nd }}$ July. In 2015 there was approximately $10 \mathrm{~cm}$ of snow in the gully on $13^{\text {th }}$ June and it was snow free by $24^{\text {th }}$ June. In 2014 , however, the gully was snow free before $14^{\text {th }}$ June. Cassiope tetragona may have had fewer flowers in 2014 than in 2013 and 2015 due to the absence of a protective snow layer and the resulting exposure may have killed the pre-formed flower buds (Inouye 2008; Semenchuk et al. 2013). Arnica angustifolia and P. capitata are perennials and their pre-formed buds are protected below ground from the cold air temperatures that are typically $-40^{\circ} \mathrm{C}$ during the winter (Soper and Powell 1985; Thompson 1994).

The strategy to maximise sexual reproductive success by pre-forming flower buds in the prior year or years can only be effective if consecutive years have a long, warm growing season; the first year must be long enough and warm enough to pre-form sufficient flower buds (Høye et al. 2007; Ellebjerg et al. 2008; Panchen and Gorelick 2015), the second year must be long enough and warm enough to produce viable seed and a subsequent year must be long enough and warm enough to produce surviving seedlings (Muller et al. 2011).

Arctic plants have low rates of sexual reproductive success and, in theory, warmer temperatures and longer growing seasons resulting from recent climate change should increase sexual reproductive success (Bliss 1971; Wookey et al. 1993; Muller et al. 2011; Alsos et al. 2013). However, the extreme events and more varied climate, also associated with recent climate change (Easterling et al. 2000a, 2000b; Semenchuk et al. 2013), might be problematic for sexual reproductive success of Arctic plants given the 2+ year cycle to produce flowers (Inouye and McGuire 1991; Inouye 2008; Semenchuk et al. 2013). The observations did not test sexual reproductive success per se, however, flower abundance can be used as a proxy for reproductive success. If there are few flowers, then the possibility of sexual reproduction is lower. 
The difference in methods between 2013 and 2014 2015 and the lack of quantitative measurements in 2013 introduces some uncertainty into the findings. However, the difference between the years is so dramatic that even if the flowers had been counted rather than estimated in 2013, the same results and conclusions would likely have been drawn.

The 2012-2015 observations at Lake Hazen may be indicative of larger-scale processes that could affect Arctic plant populations. Decreased rates of sexual reproduction resulting from increasingly greater year-toyear variation in growing conditions are likely to have important and long-lasting consequences in Arctic ecosystems (Soper and Powell 1985; Pielou 1994; Svoboda and Freedman 1994).

\section{Acknowledgements}

I would like to thank the Hamlets and Hunter and Trapper Organisations of Grise Fiord and Resolute Bay for their support of the research; field assistant Carly Casey; and Tom Hossie, Paul Sokoloff, Root Gorelick, Jeff Saarela and two anonymous reviewers for their detailed review and helpful comments on the manuscript. This research was funded by a Natural Sciences and Engineering Research Council of Canada, Canadian Graduate Scholarship (NSERC CGS), Northern Scientific Training Program travel bursaries (NSTP), Canadian Federation of University Women Beverley Jackson Fellowship, in-kind support from Parks Canada's Nunavut Field Unit and logistical support from Polar Continental Shelf Program (PCSP). This research was conducted under Parks Canada research and collections permits QUT 201313959 and QUT-2014-16198.

\section{Literature Cited}

Aiken, S. G., M. J. Dallwitz, L. L. Consaul, C. L. McJannet, R. L. Boles, G. W. Argus, J. M. Gillett, P. J. Scott, R. Elven, M. C. LeBlanc, L. J. Gillespie, A. K. Brysting, H. Solstad, and J. G. Harris. 2007. Flora of the Canadian Arctic Archipelago. Canadian Museum of Nature, Ottawa, Ontario, Canada. Accessed October 2015. http://nature.ca /aaflora/data.

Alsos, I. G., E. Muller, and P. B. Eidesen. 2013. Germinating seeds or bulbils in 87 of 113 tested Arctic species indicate potential for ex situ seed bank storage. Polar Biology 36: 819-830.

Bliss, L. C. 1971. Arctic and alpine plant life cycles. Annual Review of Ecology and Systematics 2: 405-438.

Easterling, D. R., T. R. Karl, K. P. Gallo, D. A. Robinson, K. E. Trenberth, and A. Dai. 2000a. Observed climate variability and change of relevance to the biosphere. Journal of Geophysical Research 105: 20101-20114.

Easterling, D. R., G. A. Meehl, C. Parmesan, S. A. Changnon, T. R. Karl, and L. O. Mearns. 2000b. Climate extremes: observations, modeling, and impacts. Science 289: 2068-2074.

Edlund, S. A., and B. T. Alt. 1989. Regional congruence of vegetation and summer climate patterns in the Queen Elizabeth Islands, Northwest Territories, Canada. Arctic 42: $3-23$.
Ellebjerg, S. M., M. P. Tamstorf, L. Illeris, A. Michelsen, and B. U. Hansen. 2008. Inter-annual variability and controls of plant phenology and productivity at Zackenberg. Advances in Ecological Research 40: 249-273.

Elven, R. 2003. Annotated checklist of the pan-Arctic flora (PAF) vascular plants. Accessed October 2015. http://nhm2 .uio.no/paf.

Environment Canada. 2015. Climate (national climate data and information archive). Environment Canada, Ottawa, Ontario, Canada. Accessed October 2015. http://climate .weather.gc.ca.

Fox, J. F., and G. C. Stevens. 1991. Costs of reproduction in a willow: experimental responses vs. natural variation. Ecology 72: 1013-1023.

Høye, T. T., S. M. Ellebjerg, and M. Philipp. 2007. The impact of climate on flowering in the high Arctic - the case of Dryas in a hybrid zone. Arctic, Antarctic and Alpine Research 39: 412-421.

Inouye, D. W. 2008. Effects of climate change on phenology, frost damage, and floral abundance of montane wildflowers. Ecology 89: 353-362.

Inouye, D. W., and A. D. McGuire. 1991. Effects of snowpack on timing and abundance of flowering in Delphinium nelsonii (Ranunculaceae): implications for climate change. American Journal of Botany 78: 997-1001.

Inouye, D. W., F. Saavedra, and W. Lee-Yang. 2003. Environmental influences on the phenology and abundance of flowering by Androsace septentrionalis (Primulaceae). American Journal of Botany 90: 905-910.

Mallory, C., and S. Aiken. 2012. Common Plants of Nunavut. Inhabit Media, Toronto, Ontario, Canada.

Mooney, H. A., and W. D. Billings. 1960. The annual carbohydrate cycle of alpine plants as related to growth. American Journal of Botany 47: 594-598.

Muller, E., E. J. Cooper, and I. G. Alsos. 2011. Germinability of Arctic plants is high in perceived optimal conditions but low in the field. Botany 89: 337-348.

Panchen, Z. A., and R. Gorelick. 2015. Flowering and fruiting responses to climate change of two Arctic plant species, purple saxifrage (Saxifraga oppositifolia) and mountain avens (Dryas integrifolia). Arctic Science 1: 45-58.

Panchen, Z. A., R. B. Primack, T. Aniśko, and R. E. Lyons. 2012. Herbarium specimens, photographs, and field observations show Philadelphia area plants are responding to climate change. American Journal of Botany 99: 751-756.

Pielou, E. C. 1994. A Naturalist's Guide to the Arctic. University of Chicago Press, Chicago, Illinois, USA.

Porsild, A. E., and W. J. Cody. 1980. Vascular Plants of Continental Northwest Territories, Canada. National Museum of Natural Sciences, National Museums of Canada, Ottawa, Ontario, Canada.

Semenchuk, P. R., B. Elberling, and E. J. Cooper. 2013. Snow cover and extreme winter warming events control flower abundance of some, but not all species in high Arctic Svalbard. Ecology and Evolution 3: 2586-2599.

Soper, J. H., and J. M. Powell. 1985. Botanical Studies in the Lake Hazen region, Northern Ellesmere Island, Northwest Territories, Canada. Publications in natural science 5. National Museum of Natural Sciences, National Museums of Canada, Ottawa, Ontario, Canada.

Sørensen, T. J. 1941. Temperature relations and phenology of the northeast Greenland flowering plants. Reitzels, Copenhagen, Denmark. 
Svoboda, J., and B. Freedman. 1994. Ecology of a Polar Oasis: Alexandra Fiord, Ellesmere Island, Canada. Captus Press, North York, Ontario, Canada.

Thompson, W. 1994. Climate. Pages 5.1-5.78 in Resource Description and Analysis: Ellesmere Island, National Park Reserve. Edited by Parks Canada. National Resource Conservation Section, Prairie and Northern Region, Parks Canada, Department of Canadian Heritage, Winnipeg, Manitoba, Canada.
Wookey, P. A., A. N. Parsons, J. M. Welker, J. A. Potter, T. V. Callaghan, J. A. Lee, and M. C. Press. 1993. Comparative responses of phenology and reproductive development to simulated environmental change in sub-Arctic and high Arctic plants. Oikos 67: 490-502.

Received 11 May 2015

Accepted 21 November 2015 